\title{
STK11 Gene Rearrangement
}

National Cancer Institute

\section{Source}

National Cancer Institute. STK11 Gene Rearrangement. NCI Thesaurus. Code C153516.

A molecular abnormality indicating rearrangement of the ST K11 gene. 